\title{
Crystalline Calcium Oxalate in Pandanus Odoratissimus
}

\author{
Siti Alwani Ariffin, Hannis Fadzillah Mohsin, Zolkapli Eshak \& Ibtisam Abdul Wahab \\ Faculty of Pharmacy, Universiti Teknologi MARA, 42300 Puncak Alam, Selangor Darul Ehsan, Malaysia \\ E-mail: \{alwani229,hannis,zolkapli_eshak,ibtisam\}@puncakalam.uitm.edu.my
}

\begin{abstract}
Pandanus odoratissimus (P. odoratissimus) belongs to the Pandanus genus from Pandanaceae. The research involving this coastal species was reviewed and compiled. From the literature, the pharmacognostical and phytochemical investigations including chromatographic analysis were carried out on the leaves extract. Two phenolic compounds, four lignan type compounds plus a benzofuran derivative were published as the constituents of this plant. In addition, the biological work was also conducted. This included the investigation of antioxidative, antimicrobial, anti-inflammatory and free radical scavenging activities of the fractions. In this paper, the microscopical study utilising Confocal Laser Scanning Microscopy (CLSM) and Scanning Electron Microscopy (SEM) is presented. From the photomicrographs, both fruits and leaves of $P$. odoratissimus contained singly scattered and bundles of calcium oxalate raphides, observed as acicular crystals, having the shape of narrow, long and pointed needles. In addition, another morphological type of calcium oxalate was also observed. The styloids were detected as rectangular crystals having extensions around their four edges. Previously, the styloids were found in a different Pandanus species, $P$. gasicus and Freycinetia, another genus of Pandanaceae. In summary, this is the second report of the simultaneous occurrences of two crystalline shapes from a Pandanus.
\end{abstract}

Keywords - Pandanus, calcium oxalate, microscopy

\section{INTRODUCTION}

The Pandanaceae family comprises of three genera; Pandanus, Freycinetia and Sararanga, with Pandanus being the biggest. This genus contains approximately 600 species, including Pandanus odoratissimus (P. odoratissimus) [1]. The research involving this coastal species was reviewed and compiled. From the literatures, the pharmacognostical and phytochemical investigations as well as chromatographic analysis were carried out on the leaves extracts $[2,3]$. Two phenolic compounds, four lignan type compounds plus a benzofuran derivative were published as the constituents of this plant [4]. In addition, the biological work was also conducted. This included the investigation of antioxidative [4], antimicrobial [5], antiinflammatory [6] and free radical scavenging activities of the fractions [7].

Fig. 1 and 2 show $P$. odoratissimus' plant parts, comprising of the fruit head, the fruit key and the thorny leaves. Similar to $P$. tectorius, the fruit head or bunch consists of an aggregate of many tightly bunched wedgeshaped phalanges or drupes.

These drupes are also called keys, as removing a key will allow the rest to come apart easily [8]. The shape of the fruit head in this research looks ellipsoid, with overall dimensions of $13 \mathrm{~cm}$ long by $10 \mathrm{~cm}$ diameter, while tightening 30 keys (Fig. 1).

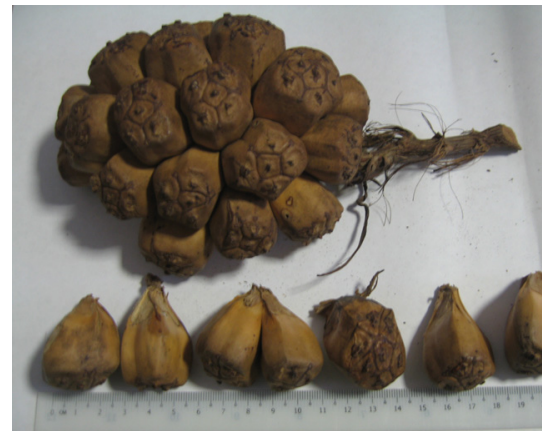

Fig. 1. The fruit head and keys of Pandanus odoratissimus

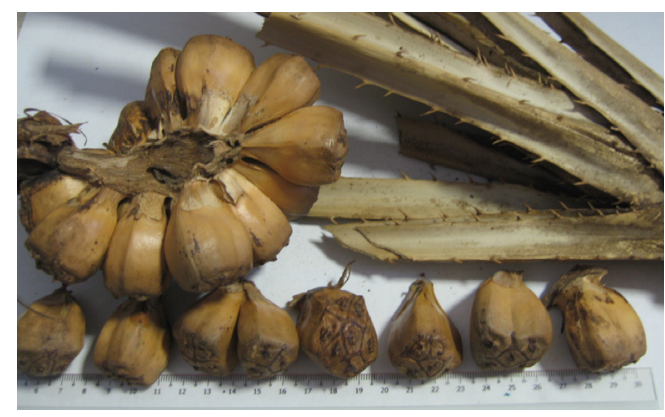

Fig. 2. Note the thorny leaves of Pandanus odoratissimus. 
The individual keys are narrowly oblong to ovoid and 5 $\mathrm{cm}$ long by $3 \mathrm{~cm}$ wide, at widest point. The outer skin (epicarp or exocarp) is very tough and hard. Meanwhile, the internal tissue surrounding the seeds (endocarp) is brown and hard, too.

In this paper, the microscopical study of $P$. odoratissimus utilising Confocal Laser Scanning Microscopy (CLSM) and Scanning Electron Microscopy (SEM) is presented. As applied to species from Cactaceae [9] and Cannaceae [10] families, the identification of calcium oxalate biomineral could be a useful tool for plant identification and chemotaxonomy. It is anticipated that the photomicrographs of Pandanus' specimen could display crystalline calcium oxalate in the needle forms called raphides $[11,12]$.

\section{Methodology}

The wild Pandanus sample for this work was collected from its coastal habitat. Fresh materials were taken from Port Dickson, Negeri Sembilan, Malaysia. Experiments were performed with specimens collected before this study and identified by the author (SAA) in January 2007. The plant parts were carefully cleaned to remove any possible external contamination [10]. They were dried, deposited at the faculty and were given voucher specimen number (POPD200607). The Pandanus were kept at the Faculty of Pharmacy, UiTM Puncak Alam, for future reference.

The crystals were extracted based on methodologies, adapted from $[11,12]$. The dried leaves were firstly cut into smaller pieces. Meanwhile, the epicarp of P. odoratissimus was sliced with a single-edge razor blade (industrial-type of carbon steel). The samples were macerated in $70 \%$ ethanol. Then, the ethanolic suspensions were agitated. The aliquots were transferred to the microscope slides and allowed to air dry. The specimens were examined by using Leica Microsystems CLSM (laser beam $=532 \mathrm{~nm}$ ), complemented with JEOL JSM-6701F SEM. All SEM analysis was carried out using an acceleration voltage of $5 \mathrm{kV}$.

\section{RESULTS \& DISCUSSION}

From the CLSM photomicrograph in Fig. 3, the leaves of $P$. odoratissimus contained a single calcium oxalate raphide. It was observed as an acicular crystal, having the shape of a narrow, long and pointed needle. The crystal could also stack together, forming a bundle of needles (Fig. 4).

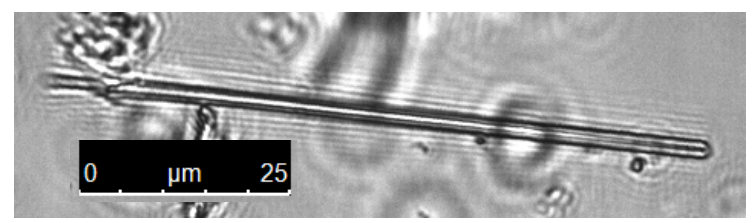

Fig. 3. The photomicrograph from $P$. odoratissimus viewed from CLSM (bar $=25 \mu \mathrm{m})$, showing a needle from the leaf sample.

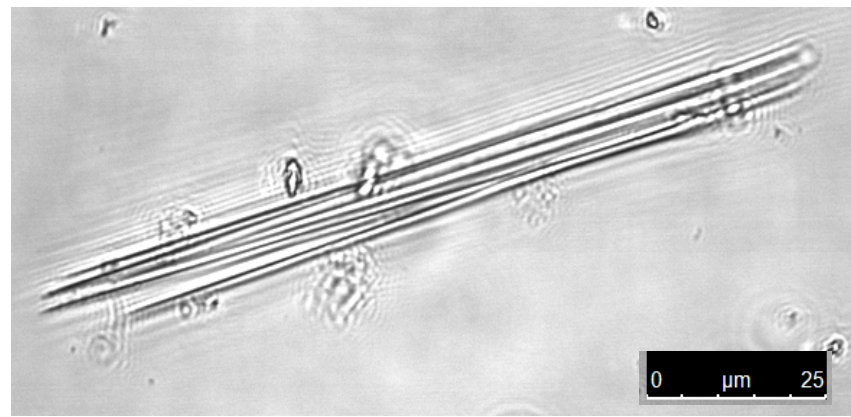

Fig. 4. The photomicrograph from $P$. odoratissimus viewed from CLSM (bar $=25 \mu \mathrm{m}$ ), showing a bundle of needles from the fruit sample.

In addition, another morphological type of calcium oxalate was also observed in the fruit of $P$. odoratissimus. The styloids were detected as rectangular crystals, some having extensions around their four edges (Fig. 5 and 6). Previously, the styloids were found in a different Pandanus species, P. gasicus and Freycinetia [13], another genus of Pandanaceae. Within the interior of a plant cell, the styloids tend to be solitary [13], unlike the needles that can be found in bundles.

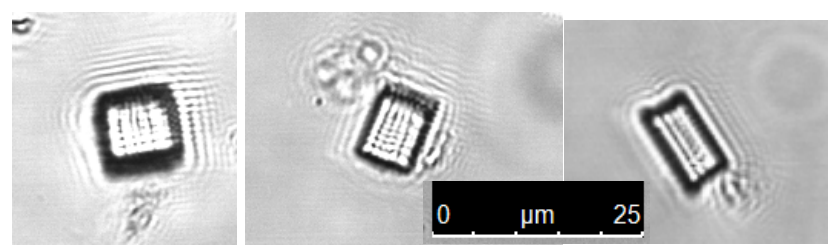

Fig. 5 The photomicrograph from $P$. odoratissimus viewed from CLSM (bar $=25 \mu \mathrm{m}$ ), showing the styloids from the fruit sample.

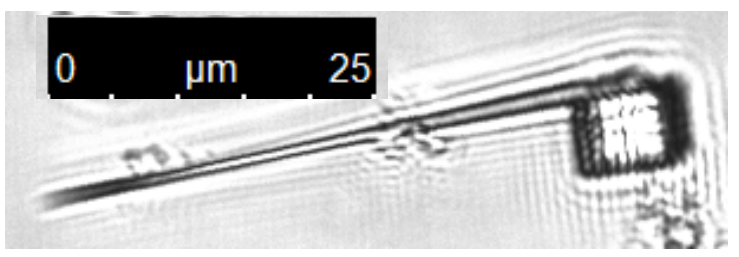

Fig. 6. The photomicrograph from P. odoratissimus viewed from CLSM (bar $=25 \mu \mathrm{m}$ ), showing both styloid and needle types of crystal from the fruit.

The presence of the crystalline calcium oxalate is also supported by the images, obtained from SEM (Fig. 7). The photomicrographs of $P$. odoratissimus' leaves and fruit showed a needle type of crystal. The mid width was 2.57 $\mu \mathrm{m}$ as seen in Fig. 7(a). Meanwhile, the length of the needle was found to be $77.43 \mu \mathrm{m}$. The summary of three identified morphological features of calcium oxalate from $P$. odoratissimus was shown in Figure 8. 


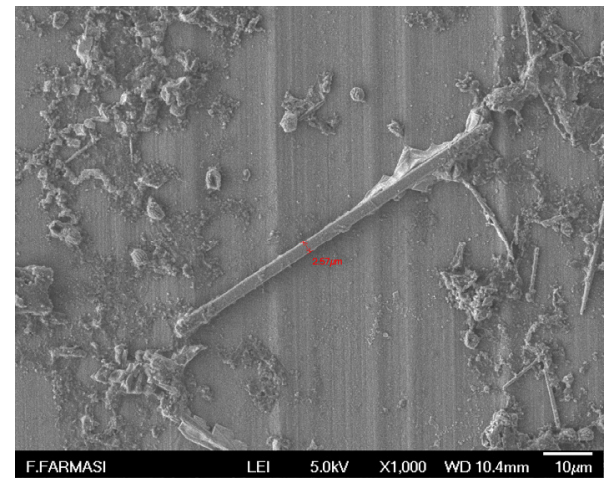

(a)

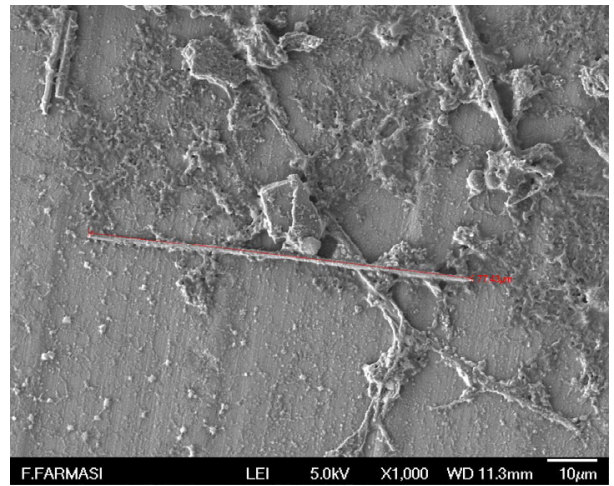

(b)

Fig. 7. The photomicrograph from $P$. odoratissimus viewed from SEM (1000x objectives, bar $=10 \mu \mathrm{m})$, showing a needle type of crystal from the (a) leaf, with a diameter of $2.57 \mu \mathrm{m}$. Meanwhile, (b) the fruit sample gave a needle with a length of $77.43 \mu \mathrm{m}$, next to a styloid.

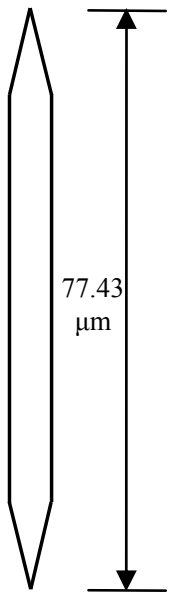

(i)
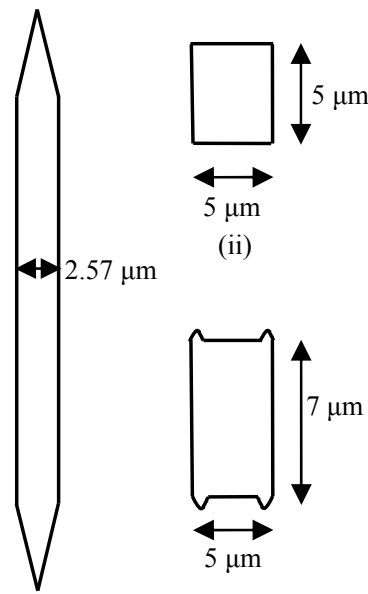

(ii)

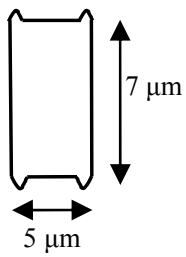

(iii)
Fig. 8. Diagram of the general summary of three identified morphological features of calcium oxalate from $P$. odoratissimus, visible by CLSM and SEM, showing (i) two pointed terminations of a needle raphide, (ii) a rectangular styloid and (iii) a styloid with extensions around its four edges.

\section{IV.CONCLUSIONS}

In conclusion, the calcium oxalate needle raphides and styloids were both observed in the leaves and fruit of Pandanus odoratissimus by utilising micro imaging applications. Therefore, this is the second report of the simultaneous occurrences of two crystalline calcium oxalate shapes from a Pandanus.

\section{ACKNOWLEDGMENT}

We would like to thank Universiti Teknologi MARA for the support.

\section{REFERENCES}

[1] J. M. Sasikumar, U. Jinu and R. Shamna. (2009) Antioxidant Activity and HPTLC Analysis of Pandanus odoratissimus L. Root. Eur. J. of Biol. Sciences, 1 (2): 17-22.

[2] V. K. Raina, Ajai Kumar, S. K. Srivastava, K. V. Syamsundar and A. P. Kahol. (2004) Essential oil composition of kewda (Pandanus odoratissimus) from India. Flavour and Fragrance Journal, 19(5), $434-436$.

[3] S. R. Chilakwad, K. P. Manjunath, K. S Akki, R. V. Savadi and N. Deshpande. (2008) Pharmacognostic and Phytochemical investigation of leaves of Pandanus odoratissimus Linn.f. Ancient Science of Life, 28 (2), 3-6.

[4] T.-T. Jong and S.-W. Chau. (1998) Antioxidative activities of constituents isolated from Pandanus odoratissimus, Phytochemistry, 49 (7), 2145-2148.

[5] R. Londonkar and A. Kamble. (2009) Antimicrobial Effects and Phytochemical Studies of Various Extracts of Pandanus Odoratissimus Linn. Trade Science Inc., Short Communication, Vol 3, Issue 3.

[6] R. Londonkar, A. Kamble and V. C. Reddy. (2010) Antiinflammatory Activity of Pandanus odoratissimus. International Journal of Pharmacology, 6(3), 311 -314.

[7] R. Londonkar and A. Kamble. (2009) Evaluation of free radical scavenging activity of Pandanus odoratissimus. International Journal of Pharmacology, 5(6): 377-380.

[8] L. A. J. Thomson, L. Englberger, L. Guarino, R. R. Thaman and C. Elevitch. (2006) Pandanus tectorius (pandanus), ver. 1.1. In: C.R. Elevitch (ed.). Species Profiles for Pacific Island Agroforestry. Permanent Agriculture Resources (PAR), Hōlualoa, Hawai‘i. $<$ http://www.traditionaltree.org $>$.

[9] P. V. Monje and E. J. Baran (2002). Characterization of Calcium Oxalates Generated as Biominerals in Cacti. Plant Physiology, 128, 707-713.

[10] E. J. Baran, A. C. González-Baró, M. M. Ciciarelli and C. H. Rolleri. (2010) Characterization of biominerals in species of Canna (Cannaceae). Biol. Trop. (Int. J. Trop. Biol.), 58 (4), 1507-1515.

[11] A. Crowther. (2009) Re-viewing raphides: Issues with the identification and interpretation of calcium oxalate crystals in microfossil assemblages, in A. Fairbairn and S. O'Connor (eds), Proceedings of the 2005 Australasian Archaeometry Conference, Terra Australis, 28, 105 - 118, published by ANU E Press, The Australian National University, Canberra, Australia.

[12] A. Crowther. (2009) Morphometric analysis of calcium oxalate raphides and assessment of their taxonomic value for archaeological microfossil studies, in Archaeological Science under a Microscope [Electronic Resource]: Studies in Residue and Ancient DNA Analysis in Honour of Thomas H. Loy / editors, Michael Haslam [et al.]. Terra Australis, 30, 102 - 128, published by ANU E Press, The Australian National University, Canberra, Australia.

[13] C. J. Prychid and P. J. Rudall. (1999) Calcium Oxalate Crystals in Monocotyledons: A Review of their Structure and Systematics. Annals of Botany, 84, 725-739. 